\title{
Wu Renshu, Paul Katz, Lin Meili (eds.), Cong chengshi kan Zhongguo de xiandaixing (The city and Chinese modernity)
}

Taipei, Institute of Modern History, Academia Sinica, 2010, 402 pages

including index.

Wen-hsin Yeh

\section{OpenEdition}

\section{Journals}

Electronic version

URL: http://journals.openedition.org/chinaperspectives/5976

DOI: 10.4000/chinaperspectives.5976

ISSN: 1996-4617

\section{Publisher}

Centre d'étude français sur la Chine contemporaine

Printed version

Date of publication: 1 October 2012

Number of pages: 88

ISSN: 2070-3449

\section{Electronic reference}

Wen-hsin Yeh, « Wu Renshu, Paul Katz, Lin Meili (eds.), Cong chengshi kan Zhongguo de xiandaixing (The city and Chinese modernity)», China Perspectives [Online], 2012/3 | 2012, Online since 01 October 2012, connection on 24 September 2020. URL : http://journals.openedition.org/chinaperspectives/ 5976 ; DOI : https://doi.org/10.4000/chinaperspectives.5976

This text was automatically generated on 24 September 2020.

(C) All rights reserved 


\section{Wu Renshu, Paul Katz, Lin Meili (eds.), Cong chengshi kan Zhongguo de xiandaixing (The city and Chinese modernity)}

Taipei, Institute of Modern History, Academia Sinica, 2010, 402 pages including index.

\section{Wen-hsin Yeh}

This richly empirical volume, which grew out of a conference held at the Institute of Modern History of the Academia Sinica, sheds new light on Chinese cities (Beijing, Suzhou, shanghai, and Chengdu) from the seventeenth to the twentieth centuries. The essays are organised under two headings: "urban life and culture" and "social groupings and urban dynamics." The volume cuts across the 1839 divide to examine the evolution of consumer culture in pre-modern and modern Chinese cities. It also cuts across the 1949 divide to examine the formation of urban entities (i.e. associations, religious groups, professions, and class) and their organised capacities for social action. The chapters speak to each other with considerable

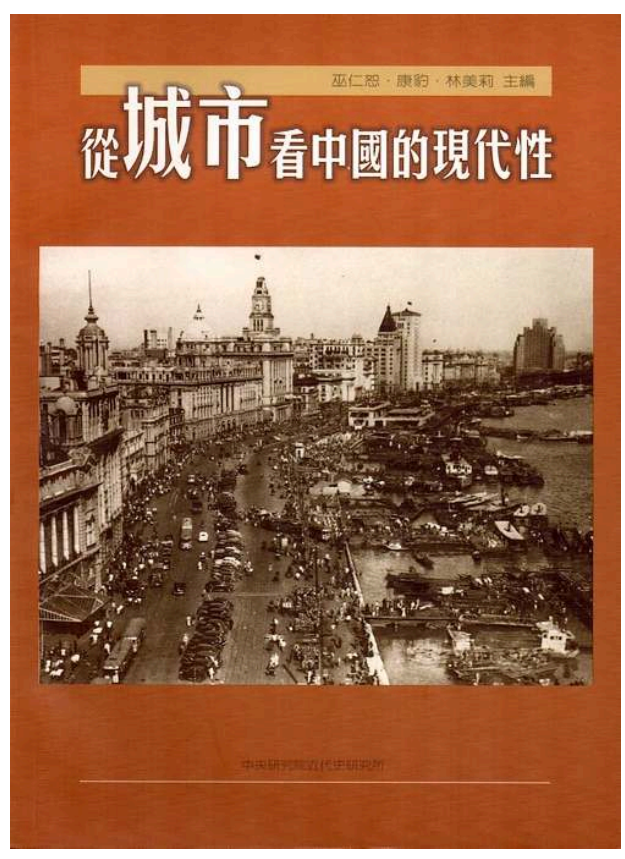
engagement. The editors, active researchers at the academy, deserve much credit for their thoughtful organisation of a rich and rewarding volume. 
2 Lai and Cheng open the volume with attention to the seventeenth century. Drawing on court archives, literati commentaries, and trade numbers, Lai shows that Manchu nobles in Beijing were avid consumers of imported Western goods such as woollen fabrics and glass products. The goods first earned favour in the imperial court, then readily inspired emulation throughout the banner community. The fashion took hold precisely because such consumption was exclusive and expensive. Cheng continues with this line of inquiry. He shows that beyond the court and the banner community, others in Chinese society also readily took up a full range of imported products - beer, cloth, clocks, and bicycles. Cheng credits general Chinese habits of consumption, rather than Manchu interest in conspicuous consumption, as a prime mover behind such adoption. Both essays muster quantitative sources to give context to the textual materials that speak to the phenomenon of robust Chinese receptiveness to new products of non-Chinese origin. The two essays combined to challenge the thesis that Qing China was ever a closed-minded empire insular in its consumer orientation. They also draw attention to the critical role of Chinese consumer culture as it functioned to selectively accept or reject new goods.

3 Lien and Chang then direct attention to Shanghai in the first quarter of the twentieth century. The authors consult not only the city's ephemeral tabloids and commercial periodicals, the bulk of which have to be rediscovered; they also delve into Shanghai's vast archives. Both authors take into account non-Chinese sources as well as nonChinese scholarship to offer comparative perspectives on the practices of shopping and gambling in industrialising cities. Lien offers close-up examinations of urban men and women seeking pleasure and diversion in Shanghai's department stores. Chang explains the ins and outs of Hai Alai matches in Shanghai and throws light on the game's East Asian debut. Department store shopping in Shanghai (much as in Chicago and Paris) offered Chinese women a space to be safely feminine and in public for the first time. This does not, of course, prevent male shoppers from sexualising the stores' female employees in conventional terms. Hai Alai matches, Chang shows, offered their spectators the excitement of speed, heat, and power embodied in Mediterranean male bodies of youth. Shanghai spectators, thanks to age-old gambling practices, transformed the matches into betting games of calculation. Female spectators meanwhile turned the games into visual consumption of exotic masculinity. Both essays succeed in "de-particularising" the Chinese consumers of the early twentieth century: i.e., they prove to be no different from consumers elsewhere in the world, nor were they different from others in having a cultural code of consumption of their own.

4 China in the twentieth century was of course not quite the same place China was in earlier times. Wu and Carroll place Suzhou at the centre of their essays. In the making of twentieth-century Suzhou, Wu shows, urban memories of past practices mattered as much as the new mode of transportation and the industrialisation of sightseeing. With trains and tour companies, time, remembered as well as experienced, became commodified in the commercialised representation of historical Suzhou. Modern tourists were thus able to access en masse scenic sites that were once exclusive during the Ming and the Qing. Carroll argues, meanwhile, that the rise of the sex industry was an even more powerful force in the spatial transformation of Republican Suzhou. Carroll's chapter offers an in-depth examination of the rise of a spatial regime centred upon the sex industry. Modernity in Suzhou, as in Shanghai, entailed the commodification of culture and sex in a new way. 
5 Sun and Wang offer, in their chapters, rich descriptions of popular mobilisations and collective actions concerning Shanghai household renters and Chengdu teahouse owners. In Sun we learn that Shanghai tenants in residential neighbourhoods got together to protest rent increases and the eviction of tenants. In Wang we learn that Chengdu teashop owners formed associations to contest state attempts to control their business practices. Both essays place emphasis on the self-directed capacities of these organisations and their eventual accommodation to the power of the state. "Modern" as the Chinese proprietors appeared to be on matters of economic interest, Liu, Fan, and Katz show that the city hosted a spiritual universe of Daoist and Buddhist beliefs, and communities of faith serving the public good were just as capable of selforganisation as their secular compatriots. $\mathrm{Xu}$ and Lin meanwhile probe the secular basis of the professionalisation and organisation of stage performers and accountants at Shanghai workplaces. Taken together, these chapters draw on a full range of urban associations formed on the basis of common interest, beliefs, and knowledge to offer a compelling portrait of Chinese cities in the first half of the twentieth century as places of vibrancy, diversity, and self-directed organised action. Iwama's final essay offers yet another informative presentation about an urban profession and its organisation. All the promises of modernity then came to an end, as Iwama shows, upon the arrival of a new political order in the 1950s. The volume, in short, makes a strong case with regard to the openness and autonomy of Chinese urban society in the decades and centuries prior to 1949.

\section{AUTHOR}

\section{WEN-HSIN YEH}

Professor of History at the University of California, Berkeley (sha@berkeley.edu). 